\title{
Discovering the Impact of ERP (Enterprise Resource Planning) Adoption toward Employee Performance
}

\author{
Anik Hanifatul Azizah ${ }^{1}$, Rokhman Fauzi ${ }^{2}$, Putra Fajar Alam ${ }^{3}$ \\ \{anikhanifazizah@gmail.com ${ }^{1}$, rokhmanfauzi@telkomuniversity.ac.id ${ }^{2}$, putrafajaralam@telkomuniversity.ac.id ${ }^{3}$ \}
}

Department of Information System, Esa Unggul University, Jakarta, Indonesia ${ }^{1}$ Department of Information System, Telkom University, Bandung, Indonesia ${ }^{2,3}$

\begin{abstract}
Enterprise Resource Planning (ERP) is a concept of planning and managing company resources involve funds, people, time, parts, materials and capacity. ERP has been widely applied in several companies in Indonesia. ERP adoption in Indonesia is ba sed on an efficiency system that can support company performance and capacity. However, ERP implementation is not that easy, failed implementation was a common occur in ERP implementation. Therefore, a dedicated model framework is needed as a reference or guideline in measuring and evaluating the success of ERP implementation. This study uses 156 respondents to fulfill a questionnaire form, from employees and top management who directly use ERP in their company. The purpose of this study is to examine the impact of ERP implementation towards the employee. This study aims to answer whether the implementation of ERP system in State-Owned Enterprise (SOEs) manufacturing sector will impact the employee's performance. The model used to evaluate the impact of ERP system implementation is Task Technology Fit. Task Technology Fit is an invalid construct that has an ability of information technology in order to support the works. The method of this study is using online questionnaire in order to collect the data that is processed by using Smart PLS 2.0. The result of this study shows that there are 8 accepted hypothesis and 4 rejected hyp othesis.
\end{abstract}

Keywords: Task Technology Fit, Enterprise Resource Planning, PLS

\section{Introduction}

The Ministry of State-Owned Enterprises (SOEs) is the institution responsible to monitor and direct the State-Owned Enterprises (SOEs). Thus the direction and strategy of the ministry are important to observe. In the SOEs strategic plan , several SOE objectives are: (1) Contribute to the development of the national economy in general and state revenue in particular(2) Realizing profit. (3) Carrying out public benefits in the formof providing high quality and sufficient goods and / or services (4) Pioneering business activities thatcannot yet be carried out by the private sector. (5) And providing guidance and assistanceto entrepreneurs. Thus, the vision of the Minis try of SOEs "Becoming a Profes sional SOE Builder to increase the value of SOEs" should be appreciated. Furthermore, the Ministry of SOEs has als oformulated the mis sion as follows: (1) Realizing a modern organization in accordance with good governance. (2) Enhancing SOE competitiveness at the national, regional and international levels. (3) Increasing the contribution of SOEs to the national economy.

In the Law No. 19 of 2003 concerning SOEs, SOEs have discretion in management. Thus SOEs has the discretion to have information technology investment. The intended information technology investment is that SOEs implement enterprise resource planning (ERP) systems with the aim of being able to increase productivity, reduce operational costs, improve accuracy of data that is mutually integrated so as to create added value and support the business activities effectively. This study discusses the relationship between ERP systems and employee tasks. The study aimed to determine the extent to which the application of enterprise resource planning is useful for employees to improve employee performance.

\section{Literature Review}

\subsection{Enterprise Resource Planning}

According to O'Brien (2005: 699), ERP (Enterprise Resource Planning) is an integrated cross -functional software that reengineers the manufacturing, distribution, financial, human resources, and other busines s processes of a company to improve its efficiency, agility and profitability. Meanwhile, according to Monk (2001: 153) ERP (Enterprise Resource Planning) is a system that helps to manage and integrate business processes such as marketing, production, purc hasing, and accounting.

The concept of ERP according to Yas in (2013), ERP (Enterprise Res ource Planning) comes from the MRP (Manufacture Resource Planning) and CIM (Computer Integrated Manufacturing) which was introduced by the research and analysis company Gartner, where theERP systemcovers all the basic functions owned by a good company, either a profit or non- 
profit oriented. ERP is a sys temthat has interrelated functions and easier to use because of the standardization that only u ses one integrated system in a company and the existence of a single database for storing the main data.

\subsection{Employee Performance}

Performance is the result obtained by an organization both the organization is profit oriented and non profit oriented which is produced over a period of time. More explicitly Amstron and Baron say Performance is the result of work that has a strong relationship with the organization's strategic objectives, customer satisfaction and economic contribution (Armstrong and Baron, 1998: 15).

\subsection{Task Technology Fit}

According to Goodhue (1995) in Irick (2008), "Task technology fit (TTF) as the degree to which a technology as sists an individual in performing his or her tasks".

Task Technology Fit or (TTF) was developed by Dale L Goodhue in 1995. The core of the TTF Model is a formal construct that is the suitability of technological capabilities for the needs of work as signments, namely the ability of information technology to provide support for work (Goodhue and Thompson 1995: 213-236).

This model was later developed by Chung in 2015 in his research on TTF in Enterprise Mobile Applications (EMA) applications.

\section{Methodology}

This study solves problems regarding the implementation ofERP systems in the SOE manufacturing sector. IT Artifacts from research are evaluating the impact of implementing an ERP sys tem by surveying the impact of implementing an ERP system. Knowledge base concept used is the TTF (Task Technology Fit) model. The evaluation was carried out by distributing questionnaires to SOEs manufacturing companies in Indonesia online.

This study uses survey research methods and includes explanatory res earch with quantitative research approaches that are reviewed by evaluative studies. This study uses a TTF model.

The hypothesis proposed in this study is as follows:

H1 :Task mobility has a positive and significant effect on task-technology fit.

H2 :Task feedback has a positive and significant effect on task-technology fit.

H3 :System Reliability has a positive and significant effect on task-technology fit.

H4 :System accessibility has a positive and significant effect on task-technology fit.

H5 :System quality has a positive and significant effect on task-technology fit.

H6 :Trust has a positive and significant effect on habitual use.

H7 :Self Efficacy has a positive and significant effect on habitual use.

H8 :Perceived Critical Mass has a positive and significant effect on habitual use.

H9 : Reputation has a positive and significant effect on habitual use.

H10 :Task Technology Fit has a positive and significant effect on Individual Performance.

H11 : Task Technology Fit has a positive and significant effect on habitual use.

H12 : Habitual Use has a positive and significant effect on Individual Performance.

\section{Result and Discussion}

\subsection{Reliability Test}

The reliability test conducted in this study is Composite Reliability. According to Gilem et al. (2003), a valid and reliable cons truct has a Composite Reliability value above 0.6 . The results obtained from data processing can be seen in Table I as follows:

TABLE I. COMPOSITE RELABILITY

\begin{tabular}{|l|c|c|}
\hline & Composite Reliability & Conclusion \\
\hline Habitual Use & 0.758970 & Reliable \\
\hline
\end{tabular}




\begin{tabular}{|l|l|l|}
\hline Individual Perfomance & 0.886129 & Reliable \\
\hline Perceived Critical Mass & 0.739173 & Reliable \\
\hline Reputation & 0.904704 & Reliable \\
\hline Self Efficacy & 0.896477 & Reliable \\
\hline System Accessbility & 0.858653 & Reliable \\
\hline System Quality & 0.933318 & Reliable \\
\hline System Reliability & 0.416026 & Not Reliable \\
\hline Task Feedback & 0.872455 & Reliable \\
\hline Task Mobility & 1.000000 & Reliable \\
\hline Task Technology Fit & 0.891114 & Reliable \\
\hline Trust & 0.822416 & Reliable \\
\hline
\end{tabular}

\subsection{ValidityTest}

Validity test is conducted to test the extent of the accuracy of the measuring instrument. The validity test conducted is Average Variant Extracted. The results obtained from data processing in Table II, as follows:

TABLE II. AVE VALUE

\begin{tabular}{|l|c|c|}
\hline & AVE & Conclusion \\
\hline Habitual Use & 0.615100 & Valid \\
\hline Individual Perfomance & 0.721788 & Valid \\
\hline Perceived Critical Mass & 0.599453 & Valid \\
\hline Reputasi & 0.826109 & Valid \\
\hline Self Efficacy & 0.742715 & Valid \\
\hline System Accessbility & 0.752514 & Valid \\
\hline System Quality & 0.874992 & Valid \\
\hline System Reliability & 0.554540 & Valid \\
\hline Task Feedback & 0.773967 & Valid \\
\hline Task Mobility & 1.000000 & Valid \\
\hline Task Technology Fit & 0.621634 & Valid \\
\hline Trust & 0.698558 & Valid \\
\hline
\end{tabular}

According to Fornell (1981), the value of AVEis above 0.5. Based on the results of AVE data in table II, the lowest value is 0.554 and the highest is 1.00 . It can be concluded that the AVEvalue in this study has met the requirements of convergent validity.

\subsection{Structural Model}

The PLS algorithm calculation results are in the following figure : 


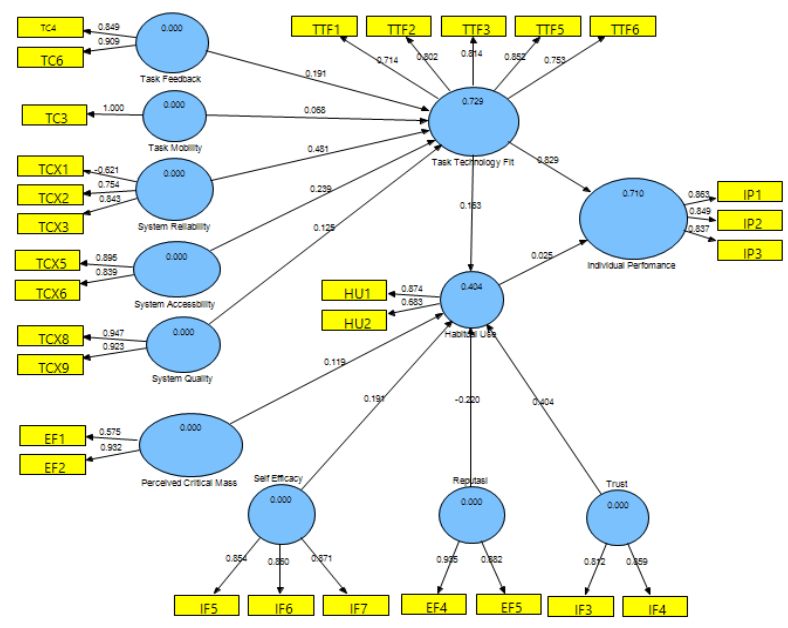

Figure 1. PLS Algorithm

\subsection{Coefficient of Determination}

R-Square (coefficient of determination) is used to assess how much influence the independent variable has on the dependent variable. R-Square values above 0.67 indicate that the model is categorized well (Chin, 1998). The results of the R-Square values in this study can be seen in table III below:

TABLE III. R-SQUARE VALUE

\begin{tabular}{|l|l|}
\hline \multicolumn{1}{|c|}{ Construct } & R-Square \\
\hline Habitual Use & 0.404102 \\
\hline Individual Perfomance & 0.710333 \\
\hline Task Technology Fit & 0.729112 \\
\hline
\end{tabular}

\subsection{Bootstrapping}

The bootstrapping process will produce path coefficient values and t-s tatis tics for hypothesis testing. Bootstrapping is done using 5000 subs amples with a significance level of $10 \%$ and a two-way test like the study conducted by Costa (2016). The results of bootstrapping data of 75 respondents are in the following figure:

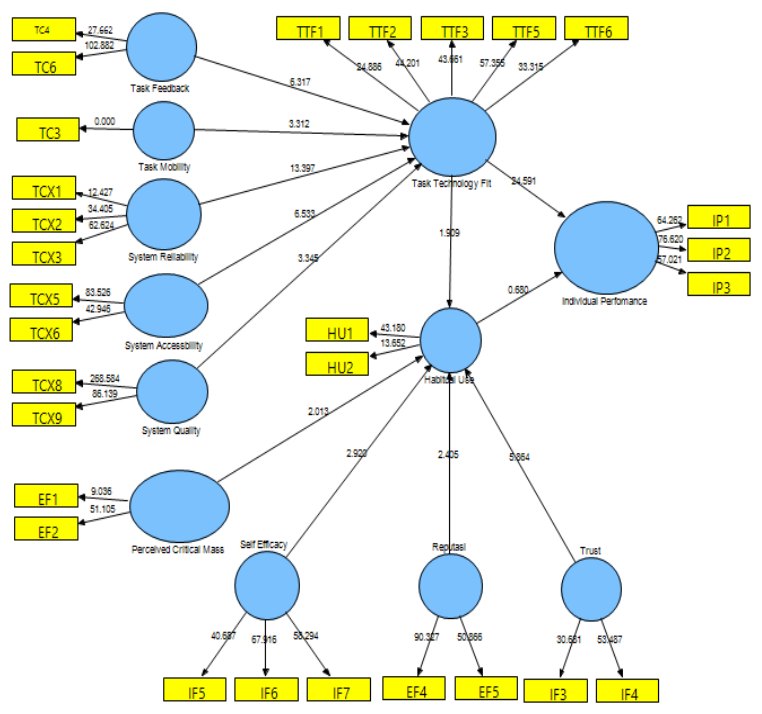

Figure 2. Bootstrapping 


\subsection{Hypothesis Testing}

Hypothesis testing is done by looking at the value of the path coefficient $(\beta)$ as a determinant of the relationship between two variables. The value of the path coefficient $(\beta)>0.1$ means the relationship between the two variables is strong. Convers ely, for values below 0.1 mean the relationship between the two variables is weak or not strong. Bootstrapping is done with 5000 subsamples and a $10 \%$ significance level bidirectional. The $t$-table value for $10 \%$ bidirectional significance is 0.166 . To test the hypothesis, it can be seen from the value of bheta or Path Coefficient $(\beta)>$ of 0.166 , meaning that the independent variable has a significant effect on the dependent variable. While the Path Coefficient $(\beta)$ value below 0.166 means that the independent variable does not affect the dependent variable. From the results of bootstrapping can be seen hypothesis testing in the following table:

TABLE IV. HYPOTHESIS RESULT

\begin{tabular}{|l|l|l|l|l|}
\hline Hypothesis & Relationship & $\begin{array}{c}\text { Path } \\
\text { Coeficient }\end{array}$ & T-value & Conclusion \\
\hline H1 & TM $\rightarrow$ TTF & 0.099427 & 3.323499 & Rejected \\
\hline H2 & TF $\rightarrow$ TTF & 0.210948 & 6.294102 & Accepted \\
\hline H3 & SR $\rightarrow$ TTF & 0.458493 & 13.491620 & Accepted \\
\hline H4 & SA $\rightarrow$ TTF & 0.231749 & 6.659130 & Accepted \\
\hline H5 & SQ $\rightarrow$ TTF & 0.127634 & 3.446438 & Rejected \\
\hline H6 & T $\rightarrow$ HU & 0.303625 & 5.990165 & Accepted \\
\hline H7 & SE $\rightarrow$ HU & 0.270151 & 2.901435 & Accepted \\
\hline H8 & PCM $\rightarrow$ HU & 0.198406 & 2.062804 & Accepted \\
\hline H9 & R $\rightarrow$ HU & -0.362779 & 2.395301 & Rejected \\
\hline H10 & TTF $\rightarrow$ IP & 0.854934 & 24.905279 & Accepted \\
\hline H11 & TTF $\rightarrow$ HU & 0.294194 & 1.839991 & Accepted \\
\hline H12 & HU $\rightarrow$ IP & -0.008881 & 0.689695 & Rejected \\
\hline
\end{tabular}

\section{Conclusion}

Based on the evaluation results related to the impact of the implementation of the ERP system on individual performance of the ERP systemit can be concluded that in general the ERP systemhas a positive impact on individual performance. This is evidenced by theresults of testing the hypothesis there are 8 hypotheses accepted and 4 hypotheses rejected. Following are the results of testing this research hypothesis:

a. H1 : Task mobility has a positive effect but not significant with task-technology fit.

b. H2: Task feedback has a positive and significant effect with task-technology fit.

c. H3: System Reliability has a positive and significant effect with task-technology fit

d. H4 : System accessibility has a positive and significant effect with task-technology fit.

e. H5 : System quality has a positive effect but not significant with task-technology fit.

f. H6: Trust has a positive effect but not significant with habitual use

g. $\quad \mathrm{H} 7$ : Self Efficacy has a positive and significant effect with habitual use.

h. H8: Perceived Critical Mass has a positive and significant effect with habitual use.

i. H9: Reputation has a negative effect but not significant with habitual use.

j. H10 : Task Technology Fit has a positive and significant effect with Individual Performance.

k. H11 : Task Technology Fit has a positive and significant effect with habitual use .

1. H12 : Habitual Use has a negative effect but not significant with Individual Performance.

\section{References}

[1] Simamora, H.B., Wicaksono, C.B.K., Toindo, H., Rudi. (2015): Tingkat Keberhasilan Implementasi Enterprise Resources Planning Di Bumn Sektor Manufaktur Di Indonesia, Journal of Binus Business, Vol. 6 No. 2, 184-195.

[2] Goodhue, Dale L. dan Ronald L., Thompson. (1995). Task-Technology Fit and Individual Performance. (19, 2; ABI/INFORM Global pg. 213). MIS Quarterly.

[3] Chung, Sunghun, Kyung Young lee, dan Jinho Choi. (2015). Exploring digital creativity in the workspace: The role of enterprisemobile applications on perceived job performance and creativity, Computers in Human Behavior 42 (2015) 93-109, ELSEVIER. 
[4] O’Leary, D. E. (2009). Enterprise Resources Planning Systems: System, Life Cycle, Electronic Commerce, and Risk . UK: Cambridge University Press.Cambridge.

[5] Muharam, A.R., Siregar, K.R. (2017) : Analisis Kinerja Individu Menggunakan Model Task Technology Fit (TTF) Pada Universitas Swasta Wilayah Bogor Menggunakan Structural Equation Modeling-Partial Least Square (SEM-PLS), journal of Universitas Telkom.

[6] Ozcelik, Y. (2013). Effects of business process reengineering on firm performance: an econometric analysis. In Business Proce ss Management (pp. 99-110). Springer, Berlin, Heidelberg.

[7] Armstrong, M., \& Baron, A. (2000). Performance management. Human resource management, 69.

[8] Irick, M. L. (2008). Task-technology fit and information systems effectiveness. Journal of Knowledge Management Practice, 9(3), 1 5 .

[9] Goodhue, D. L., \& Thompson, R. L. (1995). Task-technology fit and individual performance. MISquarterly, 213-236.

[10] Kim, M. J., Chung, N., Lee, C. K., \& Preis, M. W. (2015). Motivations and use context in mobile tourism shopping: Applying contingency and task-technology fit theories. International Journal of Tourism Research, 17(1), 13-24.

[11] O'Brien, E. J., Cook, A. E., \& Lorch Jr, R. F. (Eds.). (2015). Inferences during reading. Cambridge University Press.

[12] Nelson, C. A., \& Monk, C. S. (2001). The use of event-related potentials in the study of cognitive development. Handbook of developmental cognitive neuroscience, 125-136.

[13] Gliem, J. A., \& Gliem, R. R. (2003). Calculating, interpreting, and reporting Cronbach's alpha reliability coefficient for Li kert-type scales. Midwest Research-to-Practice Conference in Adult, Continuing, and Community Education.

[14] Fornell, C. (1981). A comparative analysis of two structural equation models: LISREL and PLS applied to market data.

[15] Chin, W. W. (1998). Commentary: Issues and opinion on structural equation modeling.

[16] Costa, J. F., Lin, S. M., Macaya, E. C., Fernández-García, C., \& Verbruggen, H. (2016). Chloroplast genomes as a tool to resolve red algal phylogenies: a case study in the Nemaliales. BMC evolutionary biology, 16(1), 205. 